\title{
Immunogenicity and Safety of COVID-19 mRNA Vaccine in STAT1 GOF Patients
}

\author{
Marketa Bloomfield ${ }^{1,2}$ (C) Zuzana Parackova $^{1} \cdot$ Jana Hanzlikova $^{3} \cdot$ Jan Lastovicka $^{1} \cdot$ Anna Sediva $^{1}$
}

Received: 22 July 2021 / Accepted: 20 October 2021 / Published online: 31 October 2021

(c) The Author(s), under exclusive licence to Springer Science+Business Media, LLC, part of Springer Nature 2021

To the Editor,

STAT1 gain-of-function (STAT1 GOF) mutations underlie chronic mucocutaneous candidiasis (CMC), a phenotypically diverse inborn error of immunity, ranging from isolated infectious susceptibility to complex immune deficiency [1]. The hypermorphic effect of the STAT1 mutation is likely due to reduced STAT3 promoter binding as a result of strong antagonizing type I and II interferon (IFN-I, IFN-II)-driven STAT1 recruitment [2]. Recently, JAK inhibitors, such as ruxolitinib, operating upstream from STATs, were shown to suppress the STAT1 response to IFNs and ameliorate the immune dysregulation [3].

The host immune response to SARS-CoV-2 infection, the cause of COVID-19 disease, is largely governed by the innate viral sensing mechanisms $[4,5]$. Following their activation in the infected cells, the upregulation of the downstream transcription factors leads to increased production of IFNs. IFNs act as ubiquitous alarm triggers for the neighboring cells, activating the JAK/STAT pathways to augment the anti-viral defenses [6].

Recently, the most severe forms of COVID-19 were shown to be associated with disrupted IFN-I signaling, either due to inborn genetic errors or the presence of anti-IFN antibodies [7, 8]. Moreover, the early therapeutic enhancement of IFN response may be beneficial in preventing the infection and lowering mortality [9].

Marketa Bloomfield

marketa.bloomfield@fnmotol.cz

1 Department of Immunology, 2nd Faculty of Medicine, Charles University in Prague and University Hospital in Motol, V Uvalu 84, Prague 15006, Czech Republic

2 Department of Pediatrics, 1st Faculty of Medicine, Charles University in Prague and Thomayer University Hospital, Prague, Czech Republic

3 Department of Immunology and Allergology, Faculty of Medicine and Faculty Hospital in Pilsen, Charles University in Prague, Pilsen, Czech Republic
Hypothetically, STAT1 GOF patients may be to some degree protected from SARS-CoV-2 infection/severe COVID-19 via the pre-emptive overactivation of IFN-I signaling, despite their otherwise immune deficient status. On the other hand, abnormally augmented IFN response may contribute to the catastrophic cytokine-driven hyperinflammation in delayed stages of COVID-19 [10]. So far, three STAT1 GOF patients were reported to suffer COVID-19 (one on ruxolitinib), all experiencing a mild course [11-13].

The mRNA-based SARS-CoV-2 vaccines activate the mechanisms of innate immunity, resulting in the production of multiple inflammatory mediators, including IFNs, which effectively promote both $\mathrm{T}$ and $\mathrm{B}$ cell-mediated response and antigen-specific immune memory [14]. The introduction of such agents into an IFN-biased environment in STAT1 GOF might amplify the immune dysregulation-related symptoms. Conversely, STAT1 GOF patients receiving JAK inhibitors, such as ruxolitinib, may have blunted vaccine response, due to the artificially suppressed JAK/STAT pathway. Recently, two STAT1 GOF CMC patients were reported to mount a normal vaccine-specific anti-spike 1 antibody response and one who failed to do so $[15,16]$.

Here, we report seven adult STAT1 GOF patients (two with novel mutations) with an uneventful course of COVID19 vaccination, and/or SARS-CoV-2 infection, including two patients receiving JAK inhibitor ruxolitinib.

\section{Results}

Seven adult Czech STAT1 GOF CMC patients (previously described p.Y68C, p.A267V, p.M390T and novel p.T288N and p.E29A; cohort characteristics detailed in Supplementary Table 1) received SARS-CoV-2 spike 1 protein-encoding mRNA vaccine (Comirnanty ${ }^{\circledR}$, Pfizer/BioNTech). All seven received two doses, six of them 3 to 6 weeks apart, one patient 4 months apart. Two patients were receiving ruxolitinib at the time of vaccination. No adverse events were 
noted during 1-4-month follow-up. The antibody response was determined prior to the vaccination (Enzyme immunoassay COVID-19 RBD by TestLine Clinical Diagnostics, Czech Republic) and 3-5 weeks after the second vaccine dose (Microblot-Array COVID-19 by TestLine Clinical Diagnostics, Czech Republic). Four seronegative patients achieved vaccine-specific receptor-binding domain spike protein (RBD) IgG seroconversion (median 1211.5, range 999-1347 U/ml), which was comparable to vaccinated healthy controls $(N=100$, median 985.5 , range 470-1924 $\mathrm{U} / \mathrm{ml}$ ). Only two patients responded with anti-RBD IgA, compared to 76 out of 100 healthy controls. This may be an important efficacy parameter, as serum IgA was shown to be an early SARS-CoV-2-neutralizing agent [17]. Despite the absence of any previous COVID-19 symptoms, one patient $\left(\mathrm{P}^{\mathrm{M} 390 \mathrm{~T}}\right)$ was found to be $\mathrm{S} 1$-spike protein seropositive before vaccination, and one patient $\left(\mathrm{P} 4{ }^{\mathrm{A} 267 \mathrm{~V}}\right.$, unavailable for testing prior to vaccination) had anti-nucleocapsid, as well as anti-RBD antibodies after vaccination, suggestive of past infections in both patients. One patient did not mount an antibody response after vaccination ( $\mathrm{P}^{\mathrm{E} 29 \mathrm{~A}}$ ) (Fig. 1A). Regardless of the serologic status, six out of seven patients (one patient not tested), including the two ruxolitinib receivers, were found to mount a virus-specific (S1-spike protein) cellular immune response (median 1192.5, range $585-4115 \mathrm{mIU} / \mathrm{ml})$, which was comparable to vaccinated healthy controls $(N=7$, median 1830 , range $675-1735 \mathrm{mIU} /$ $\mathrm{ml}$ ), detected by whole blood IFN- $\gamma$ release assay (EUROIMMUN SARS-CoV-2 IGRA, Germany) (Fig. 1B). The summary of the humoral and cellular COVID-19-related immune parameters is listed in Table 1.
Within the cohort, two patients were of particular interest. An 18-year-old female P5 ${ }^{\mathrm{M} 390 \mathrm{~T}}$ with $\mathrm{CMC}$ and severe pulmonary damage had asymptomatic COVID-19 infection, as evident by anti-S1 seropositivity prior to vaccination. Despite that, the anti-nucleocapsid antibodies were not detectable. This patient has been on ruxolitinib $(0.4 \mathrm{mg} /$ $\mathrm{kg} /$ day, dose titered to healthy control's phosphorylated STAT1 level) for the past 6 months; however, it is unknown whether the infection occurred prior or after the JAK inhibitor initiation.

The second patient, a 45-year-old male $\mathrm{P}^{\mathrm{E} 29 \mathrm{~A}}$ with CMC, severe pneumopathy, and multiple autoimmune phenomena, was vaccinated while COVID-19 naïve and 5 months on ruxolitinib $(0.2 \mathrm{mg} / \mathrm{kg} /$ day, dose titered to healthy control's phosphorylated STAT1 level). The patient failed to produce detectable SARS-CoV-2 antibodies. However, this may be attributed to continuing B cell impairment after previous CD20-depletion therapy (rituximab) 18 months prior to vaccination; while the overall CD19 B cells count represented $5.7 \%$ of lymphocytes, the B cell pool constituted predominantly of CD27 negative naïve $\mathrm{B}$ cells prior to vaccination. In fact, such skewed antibody response to primary antigen exposure post-rituximab has been reported by multiple studies, including, recently, the impaired response to SARSCoV-2 vaccines $[16,18]$. Nevertheless, the patient developed a strong S1-peptide-specific T cell immune response in IGRA, interestingly, the strongest in our cohort (4115 $\mathrm{mIU} / \mathrm{ml}$; Fig. 1B).

In summary, while limited by the cohort size and the absence of antibody-neutralization assays, our observations indicate that SARS-CoV-2 mRNA vaccination in
Fig. 1 Immune responses to SARS-CoV-2 mRNA vaccine (Pfizer/BioNTech) in STAT1 GOF patients evaluated 3-5 weeks after the second vaccine dose. A Antibody titers in 7 patients determined by Microblot-Array COVID-19 (TestLine Clinical Diagnostics, Brno, Czech Republic); results are compared to vaccinated healthy controls $(N=100)$ and considered positive if value is $>210 \mathrm{U} /$ $\mathrm{ml}$. B S1-spike protein-specific $\mathrm{T}$ cell immune response in 6 patients determined by EUROIMMUN SARS-CoV-2 IGRA, Lübeck, Germany; results are compared to vaccinated healthy controls $(N=7)$ and considered positive if value $>200 \mathrm{mIU} / \mathrm{ml}$. $\mathrm{CMC}$, chronic mucocutaneous candidiasis; RBD, receptorbinding domain spike protein; $\mathrm{S} 1$, spike 1 protein
A IgG RBD
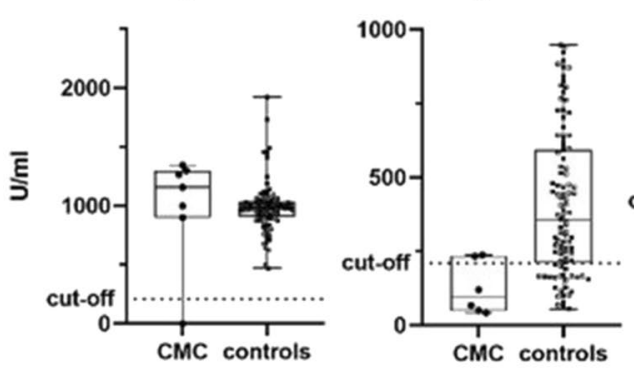
IgG Nucleocapsid
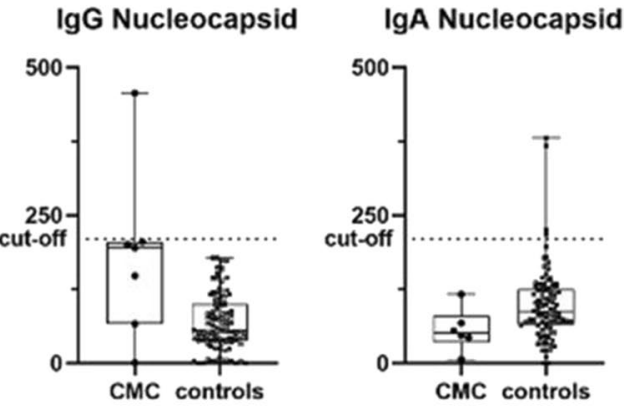

B

S1-specific $T$ cell response

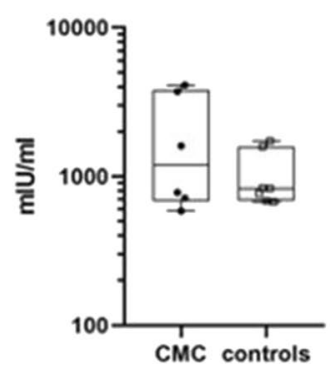

IgA RBD

CMC controls 
Table 1 Overview of COVID-19-related immune status of 7 STAT1 GOF patients

\begin{tabular}{|c|c|c|c|c|c|c|c|c|c|}
\hline & $\begin{array}{l}\text { Past } \\
\text { COVID-19 } \\
\text { symptoms/ } \\
\text { confirmed } \\
\text { infection }\end{array}$ & $\begin{array}{l}\text { Pre-vaccina- } \\
\text { tion SARS- } \\
\text { CoV-2 } \\
\text { anti-RBD }\end{array}$ & $\begin{array}{l}\text { Post- } \\
\text { vaccination } \\
\text { SARS-CoV-2 } \\
\text { anti-RBD } \\
\text { IgG }\end{array}$ & $\begin{array}{l}\text { Post- } \\
\text { vaccination } \\
\text { SARS-CoV-2 } \\
\text { anti-RBD } \\
\text { IgA }\end{array}$ & $\begin{array}{l}\text { Post- } \\
\text { vaccination } \\
\text { SARS- } \\
\text { CoV-2 anti- } \\
\text { NC IgG }\end{array}$ & $\begin{array}{l}\text { Post- } \\
\text { vaccination } \\
\text { SARS- } \\
\text { CoV-2 anti- } \\
\text { NC IgA }\end{array}$ & $\begin{array}{l}\text { Post- } \\
\text { vaccination } \\
\text { S1-specific } \\
\text { IGRA }\end{array}$ & $\begin{array}{l}\text { Interval } \\
\text { between } 2 \text { nd } \\
\text { vaccine dose } \\
\text { and testing } \\
\text { (weeks) }\end{array}$ & $\begin{array}{l}\text { Immune } \\
\text { therapy at } \\
\text { time of vac- } \\
\text { cination }\end{array}$ \\
\hline $\mathrm{P} 1^{\mathrm{Y} 68 \mathrm{C}}$ & - & - & + & + & - & - & + & 3 & - \\
\hline $\mathrm{P} 2{ }^{\mathrm{Y} 68 \mathrm{C}}$ & - & - & + & + & - & - & + & 3 & IgRT \\
\hline $\mathrm{P} 3^{\mathrm{A} 267 \mathrm{~V}}$ & - & - & + & - & - & - & ND & 5 & - \\
\hline $\mathrm{P} 4^{\mathrm{A} 267 \mathrm{~V}}$ & - & ND & + & - & + & - & + & 3 & - \\
\hline $\mathrm{P}^{\mathrm{M} 390 \mathrm{~T}}$ & - & $\mathrm{IgG}+/ \operatorname{IgA}+$ & + & - & - & - & + & 3 & $\begin{array}{l}\text { Ruxolitinib } \\
\text { IgRT }\end{array}$ \\
\hline$P 6^{\mathrm{T} 288 \mathrm{~N}}$ & - & - & + & - & - & - & + & 3 & - \\
\hline $\mathrm{P} 7^{\mathrm{E} 29 \mathrm{~A}}$ & - & - & - & - & - & - & + & 4 & $\begin{array}{l}\text { Ruxolitinib } \\
\text { IgRT } \\
\text { Rituximab } \\
18 \text { months } \\
\text { pre-vacci- } \\
\text { nation }\end{array}$ \\
\hline
\end{tabular}

+ , positive; -, negative; $R B D$, receptor-binding domain spike protein; $N C$, nucleocapsid protein; $N D$, not done; IGRA, IFN- $\gamma$ release assay; $\operatorname{IgRT}$, immunoglobulin replacement therapy

STAT1 GOF is immunogenic and may be safe, even during treatment with JAK inhibitor and after past infection. Furthermore, we affirm that COVID-19 disease may take a mild/asymptomatic course in STAT1 GOF CMC. This data may help guide clinical counselling for patients with STAT1 GOF CMC.

Supplementary Information The online version contains supplementary material available at https://doi.org/10.1007/s10875-021-01163-8.

\begin{abstract}
Author Contribution MB treated the patients, established the hypothesis, and wrote the manuscript. ZP established the hypothesis and cowrote the manuscript. JH treated the patient and co-organized the sampling. JL carried out the testing and analyzed the samples. AS treated the patients and supervised the manuscript preparation and revisions. All authors reviewed the manuscript.
\end{abstract}

Funding This work was supported by grants NV18-05-00162 from Ministry of Health of the Czech Republic, MH CZ-DRO (Thomayer University Hospital-TUH, 00064190) and by Jeffrey Modell Center Networks Research grant.

Data Availability On a reasonable request, the data supporting study's findings are available from the corresponding author.

Code Availability Not applicable.

\section{Declarations}

Ethics Approval Ethical review and approval was not required for the study on human participants in accordance with the local legislation and institutional requirements.
Consent to Participate and Publish Written informed consent to participate in this study and for publication was provided by all the participants of the study.

Conflict of Interest The authors declare no competing interests.

\section{References}

1. Toubiana J, Okada S, Hiller J, Oleastro M, Gomez ML, Becerra JCA, Ouachée-Chardin M, Fouyssac F, Girisha KM, Etzioni A, et al. Heterozygous STAT1 gain-of-function mutations underlie an unexpectedly broad clinical phenotype. Blood. 2016;127:315464. https://doi.org/10.1182/blood-2015-11-679902.

2. Zheng J, van de Veerdonk FL, Crossland KL, Smeekens SP, Chan CM, Al Shehri T, Abinun M, Gennery AR, Mann J, Lendrem DW, et al. Gain-of-function STAT1 mutations impair STAT3 activity in patients with chronic mucocutaneous candidiasis (CMC). Eur J Immunol. 2015;45:2834-46. https://doi.org/10.1002/eji.20144 5344.

3. Forbes LR, Vogel TP, Cooper MA, Castro-Wagner J, Schussler E, Weinacht KG, Plant AS, Su HC, Allenspach EJ, Slatter M, et al. Jakinibs for the treatment of immune dysregulation in patients with gain-of-function signal transducer and activator of transcription 1 (STAT1) or STAT3 mutations. J Allergy Clin Immunol. 2018;142. https://doi.org/10.1016/j.jaci.2018.07.020.

4. Lim Y, Ng Y, Tam J, Liu D. Human coronaviruses: a review of virus-host interactions. Diseases. 2016;4. https://doi.org/10.3390/ diseases4030026.

5. Fitzgerald KA, Kagan JC. Toll-like receptors and the control of immunity. Cell. 2020;180. https://doi.org/10.1016/j.cell.2020.02. 041.

6. Li SF, Gong MJ, Zhao FR, Shao JJ, Xie YL, Zhang YG, Chang HY. Type i interferons: distinct biological activities and current applications for viral infection. Cell Physiol Biochem. 2018;51. https://doi.org/10.1159/000495897. 
7. Bastard P, Rosen LB, Zhang Q, Michailidis E, Hoffmann HH, Zhang Y, Dorgham K, Philippot Q, Rosain J, Béziat V, et al. Autoantibodies against type I IFNs in patients with life-threatening COVID-19. Science (80- ). 2020;370. https://doi.org/10.1126/ science.abd4585.

8. Zhang Q, Liu Z, Moncada-Velez M, Chen J, Ogishi M, Bigio B, Yang R, Arias AA, Zhou Q, Han JE, et al. Inborn errors of type I IFN immunity in patients with life-threatening COVID-19. Science (80- ). 2020;370. https://doi.org/10.1126/science.abd4570.

9. Jirjees F, Saad AK, Al Hano Z, Hatahet T, Al Obaidi H, Dallal Bashi YH. COVID-19 treatment guidelines: do they really reflect best medical practices to manage the pandemic? Infect Dis Rep. 2021;13:259-84. https://doi.org/10.3390/idr13020029.

10. Wang N, Zhan Y, Zhu L, Hou Z, Liu F, Song P, Qiu F, Wang $\mathrm{X}$, Zou X, Wan D, et al. Retrospective multicenter cohort study shows early interferon therapy is associated with favorable clinical responses in COVID-19 patients. Cell Host Microbe. 2020;28:455-464.e2. https://doi.org/10.1016/j.chom.2020.07.005.

11. Guisado Hernández P, Blanco Lobo P, Villaoslada I, de Felipe B, Lucena JM, Martín Gutierrez G, Castro MJ, Gutiérrez Valencia A, Sánchez Codez MI, Gaboli M, et al. SARS-CoV-2 infection in a pediatrics STAT1 GOF patient under ruxolitinib therapy-a matter of balance? J Clin Immunol. 2021;1-5. https://doi.org/10.1007/ s10875-021-01081-9.

12. Meyts I, Bucciol G, Quinti I, Neven B, Fischer A, Seoane E, Lopez-Granados E, Gianelli C, Robles-Marhuenda A, Jeandel $\mathrm{P}-\mathrm{Y}$, et al. Coronavirus disease 2019 in patients with inborn errors of immunity: an international study. J Allergy Clin Immunol. 2021;147:520-31. https://doi.org/10.1016/j.jaci.2020.09.010.

13. Esenboga S, Ocak M, Akarsu A, Bildik HN, Cagdas D, Iskit AT, Tezcan I. COVID-19 in patients with primary immunodeficiency. J Clin Immunol. 2021. https://doi.org/10.1007/ s10875-021-01065-9.
14. Pardi N, Hogan MJ, Porter FW, Weissman D. mRNA vaccines a new era in vaccinology. Nat Rev Drug Discov. 2018;17:261-79. https://doi.org/10.1038/nrd.2017.243.

15. Hagin D, Freund T, Navon M, Halperin T, Adir D, Marom R, Levi I, Benor S, Alcalay Y, Freund NT. Immunogenicity of PfizerBioNTech COVID-19 vaccine in patients with inborn errors of immunity. J Allergy Clin Immunol. 2021;148:739-49. https://doi. org/10.1016/j.jaci.2021.05.029.

16. Delmonte OM, Bergerson JRE, Burbelo PD, Durkee-Shock JR, Dobbs K, Bosticardo M, Keller MD, McDermott DH, Rao VK, Dimitrova D, Quiros-Roldan E, Imberti L, Ferrè EMN, Schmitt M, Lafeer C, Pfister J, Shaw D, Draper D, Truong M, Ulrick J, DiMaggio T, Urban A, FA. Antibody responses to the SARS-CoV-2 vaccine in individuals with various inborn errors of immunity. $\mathrm{J}$ Allergy Clin Immunol. 2021; 4:0091-6749(21)01356-7.

17. Delphine S, Alexis M, Makoto M, Audrey M, François A, Laetitia C, Paul Q, Jehane F, Hervé D, Pascale G, et al. IgA dominates the early neutralizing antibody response to SARS-CoV-2. Sci Transl Med. 2021;13:abd2223. https://doi.org/10.1126/scitranslmed. abd2223.

18. Mrak D, Tobudic S, Koblischke M, Graninger M, Radner H, Sieghart D, Hofer P, Perkmann T, Haslacher H, Thalhammer $\mathrm{R}$, et al. SARS-CoV-2 vaccination in rituximab-treated patients: B cells promote humoral immune responses in the presence of T-cell-mediated immunity. Ann Rheum Dis. 2021;annrheumdis-2021-220781. https://doi.org/10.1136/annrh eumdis-2021-220781.

Publisher's Note Springer Nature remains neutral with regard to jurisdictional claims in published maps and institutional affiliations. 